\title{
Hepatic metallothionein and heavy metals in dab Limanda limanda from the German Bight
}

\author{
Ketil Hylland ${ }^{1}$, Carl Haux ${ }^{2}$, Christer Hogstrand ${ }^{2}$ \\ 'Division of Marine Zoology and Marine Chemistry, Department of Biology, University of Oslo, PB 1064, Blindern, \\ N-0316 Oslo, Norway \\ ${ }^{2}$ Department of Zoophysiology, University of Göteborg, PO Box 25059, S-400 31 Göteborg, Sweden
}

\begin{abstract}
During the Bremerhaven Workshop, the effect of heavy metals on dab Limanda limanda L. in the German Bight was assessed using the hepatic level of metallothionein (MT) and selected metals. Male and female adult dab were collected at 7 stations on a transect from the Elbe and Weser estuaries towards the Dogger Bank. Metallothionein, $\mathrm{Cu}, \mathrm{Zn}$ and $\mathrm{Cd}$ concentrations in dab livers were determined using radioimmunoassay (RIA) and atomic absorption spectrophotometry (AAS). Hepatic MT levels were highest in both male and female dab at some of the offshore stations, decreasing towards the coast and towards the Dogger Bank. The levels of MT in dab livers reflected the hepatic concentration of metal in all dab, but the relative importance of specific metals differed between the sexes. In female dab, the best correlation was found between hepatic MT and Zn, whereas MT in male dab livers correlated most closely to a combination of $\mathrm{Cu}$ and $\mathrm{Cd}$. The observed changes in hepatic MT appeared to have both an endogenous and an environmental component. The endogenous influence was only evident in female dab, whereas both sexes appeared to be moderately affected by environmental metal exposure. Hepatic MT and metal levels did not reflect metal concentrations in the sediment, but were consistent with the elevated metal content of 2 invertebrate species at offshore compared to coastal stations. In conclusion, dab hepatic MT was found useful as a biomarker for the effects of heavy metals on fish in an area with a complex contaminant input. Recommendations are given for future use of fish hepatic MT in monitoring programmes.
\end{abstract}

\section{INTRODUCTION}

Management and conservation of marine resources require means to establish and predict the impact of single contaminants and contaminant mixtures on individual organisms, populations and communities. Methods in use at present range from the analysis of single proteins in specific organs of an individual to assessment of the structure of entire communities (Haux \& Förlin 1988, 1989). The main advantages of subcellular biomarkers are that they are affected at an early stage in a potentially harmful process and that most biomarkers are specific towards a contaminant, or a group of contaminants. As regards environmental contamination by metals, the protein metallothionein (MT) has the widest scope and largest potential as a subcellular biomarker, both in fish and in other aquatic organisms (Engel \& Roesijadi 1987, Engel \& Brouwer 1989).
Metallothionein is a low molecular weight, cysteinerich, water-soluble protein found in all vertebrates and some invertebrates (George 1990). Primarily a Cu- and $\mathrm{Zn}$-binding protein during normal metabolism, MT is induced by and binds $\mathrm{Cu}$ and $\mathrm{Zn}$, as well as $\mathrm{Cd}$ and $\mathrm{Hg}$, following environmental exposure. Induction of the protein in feral fish has been found to be associated with increased levels of $\mathrm{Cu}, \mathrm{Zn}, \mathrm{Cd}$ or $\mathrm{Hg}$ (Hogstrand \& Haux 1991). However, some studies on fish describe effects on MT levels, or on the metal composition of MT by other exogenous (Sabourin et al. 1986, Baer \& Thomas 1990) and endogenous (Hyllner et al. 1989) factors.

Fish hepatic metallothionein has been employed as a biological marker of heavy metal pollution in both freshwater and marine environments. In several investigations (Roch \& McCarter 1984, Olsson \& Haux 1986. Hogstrand \& Haux 1990a, Hogstrand et al. 1991, 
Sulaiman et al. 1991) a relationship was found between elevated environmental metal levels and MT induction, and hepatic metal concentrations correlated to the level of MT. There are only a limited number of studies in areas with complex contaminant mixtures, and increases of hepatic metal content or MT induction at elevated ambient metal concentrations are not always apparent (Brown et al. 1982, Overnell \& Abdullah 1988).

The German Bight is an area with inputs of a wide range of contaminants and there were therefore 2 main objectives for the present study. First, to evaluate the impact of $\mathrm{Cu}, \mathrm{Zn}$ and $\mathrm{Cd}$ on dab in the German Bight and, second, to evaluate the suitability of hepatic MT in flatfish for monitoring purposes in an area with a complex pollution load. Since the fish were collected during a period of sexual maturation and spawning (cf. Daan et al. 1990), an attempt was also made to evaluate whether reproductive status afiects hepatic metallothionein levels in male and female dab.

\section{MATERIALS AND METHODS}

Collection and sample treatment. Dab Limanda $1 i$ manda L. were collected at 7 stations in the German Bight in March 1990 using a bottom trawl. The stations designated 1 \& 3 were close to the Elbe estuary, the remaining stations forming a transect ending at Stn 9 on the eastern edge of the Dogger Bank. Male and female dab within the size range 20 to $25 \mathrm{~cm}$ (adults) were used in the present study. The livers were dissected from freshly caught fish and divided at random into 4 or 5 parts to enable various biochemical analyses to be performed on the same liver. Liver pieces were wrapped in aluminium foil and frozen separately in liquid nitrogen. The samples were transported on dryice and then kept at $-80^{\circ} \mathrm{C}$ until used. One or more liver pieces from each individual were weighed and homogenized in at least $1: 2(\mathrm{w} / \mathrm{v}) 50 \mathrm{mM}$ Tris $-\mathrm{HCl}, \mathrm{pH}$ 8.1. A $500 \mu \mathrm{l}$ aliquot of the homogenate was removed for metal analysis and the remainder centrifuged at $10000 \times \mathrm{g}$. The resulting supernatant was frozen at $-80^{\circ} \mathrm{C}$ until further use. Liver samples were homogenized in batches according to site, but were thereafter randomly mixed before analyses for metals and MT. Male and female samples were treated separately.

Metal analysis. Nitric acid, $\mathrm{HNO}_{3},(2.5 \mathrm{ml})$ was added to a $500 \mu \mathrm{l}$ aliquot of homogenate, the solution kept at $110^{\circ} \mathrm{C}$ until clear and then $400 \mu \mathrm{H}_{2} \mathrm{O}_{2}$ was added. The resulting solution was evaporated at $110^{\circ} \mathrm{C}$ to near-dryness, and then brought up to $4 \mathrm{ml}$ using deionized water (Millipore, Bedford, MA, USA). Appropriately diluted samples were then analyzed using flame $(\mathrm{Zn})$ and electrothermal $(\mathrm{Cu}, \mathrm{Cd})$ atomic absorption spectrophotometry with Smith-Heftje and deuterium background correction (Instrumentation Laboratories Video 12 and Varian SpectrAA 10 instruments, respectively). Metal standards were made up in $1 \% \mathrm{HNO}_{3}$. Blanks of buffer only were included in all batches.

Metallothionein analysis. Hepatic MT was determined using a double antibody radioimmunoassay (RIA) with rabbit antiserum raised against $M T$ from perch Perca fluviatilis as the first antibody and goat anti-rabbit IgG (Bio-Rad, Richmond, CA, USA) as the second. ${ }^{125}$ I-labelled perch MT was used as tracer (Hogstrand \& Haux 1990b). The MT standard used was $10000 \times g$ supernatant of a liver homogenate from untreated dab. The MT content of the standards was calibrated using differential pulse polarography (Olafson \& Sim 1979, Hogstrand \& Haux 1992).

Statistical methods. Differences in hepatic $\mathrm{Cu}_{1} \mathrm{Zn}$, C.d and MT concentrations in dab of either sex collected at different stations were tested statistically using 1 -way analysis of variance (ANOVA) on $\log _{e}$-transformed data (Sokal \& Rohlf 1981). If significant differences were found $(p<0.05)$, Tukey's HSD-test was used in a pairwise comparison between all stations (cf. Day \& Quinn 1989). The relationships between MT concentrations and metals ( $\mathrm{Cu}, \mathrm{Zn}, \mathrm{Cd})$ in individual dab of each sex were evaluated using multiple regression analysis on $\log _{e}$-transformed values with hepatic MT as the dependent variable (Snedecor \& Cochran 1980). Each of the metals was then successively removed from the regression to determine its relative contribution to account for the total variation, and to evaluate which combination of metals would relate most closely to MT concentrations. In addition, the relationships between hepatic metal (Cu, $\mathrm{Zn}, \mathrm{Cd})$ and MT concentrations in all individuals of either sex were evaluated using Spearman's correlation analysis (Siegel 1956). Differences in hepatic MT levels between male and female dab at each station were tested using an unpaired Student t-test on $\log _{e}$-transformed data (Sokal \& Rohlf 1981).

\section{RESULTS}

\section{$\mathrm{Cu}, \mathrm{Zn}$ and $\mathrm{Cd}$ in dab liver}

The mean hepatic Cu concentration varied between $5.5 \mu \mathrm{g} \mathrm{g}^{-1}$ (Stn 9) and $16 \mu \mathrm{g} \mathrm{g}^{-1}$ wet wt (Stn 3) in female dab, and these 2 stations were the only ones found to be significantly different (Fig. 1A). The mean level of $\mathrm{Zn}$ in female livers ranged from 27.7 to $39.2 \mathrm{\mu g} \mathrm{g}^{-1}$ at different stations, and Cd from 0.22 to $0.33 \mu \mathrm{g} \mathrm{g}^{-1}$ wet wt. There were no significant differences between stations for either $\mathrm{Zn}$ or $\mathrm{Cd}$ (Fig 1B, C). 
In male dab, there was less inter-station variability with regard to $\mathrm{Cu}$, and the mean concentration varied from 4.3 to $10.4 \mu_{\mathrm{g} \mathrm{g}^{-1}}$ wet wt. The hepatic Cu level in males from Stns $1 \& 9$ was significantly lower than in males from Stns 3, 7 \& 8 (Fig. 1D). The zinc concentration in male livers varied from 27.4 to $33.7 \mu \mathrm{g} \mathrm{g}^{-1}$ wet
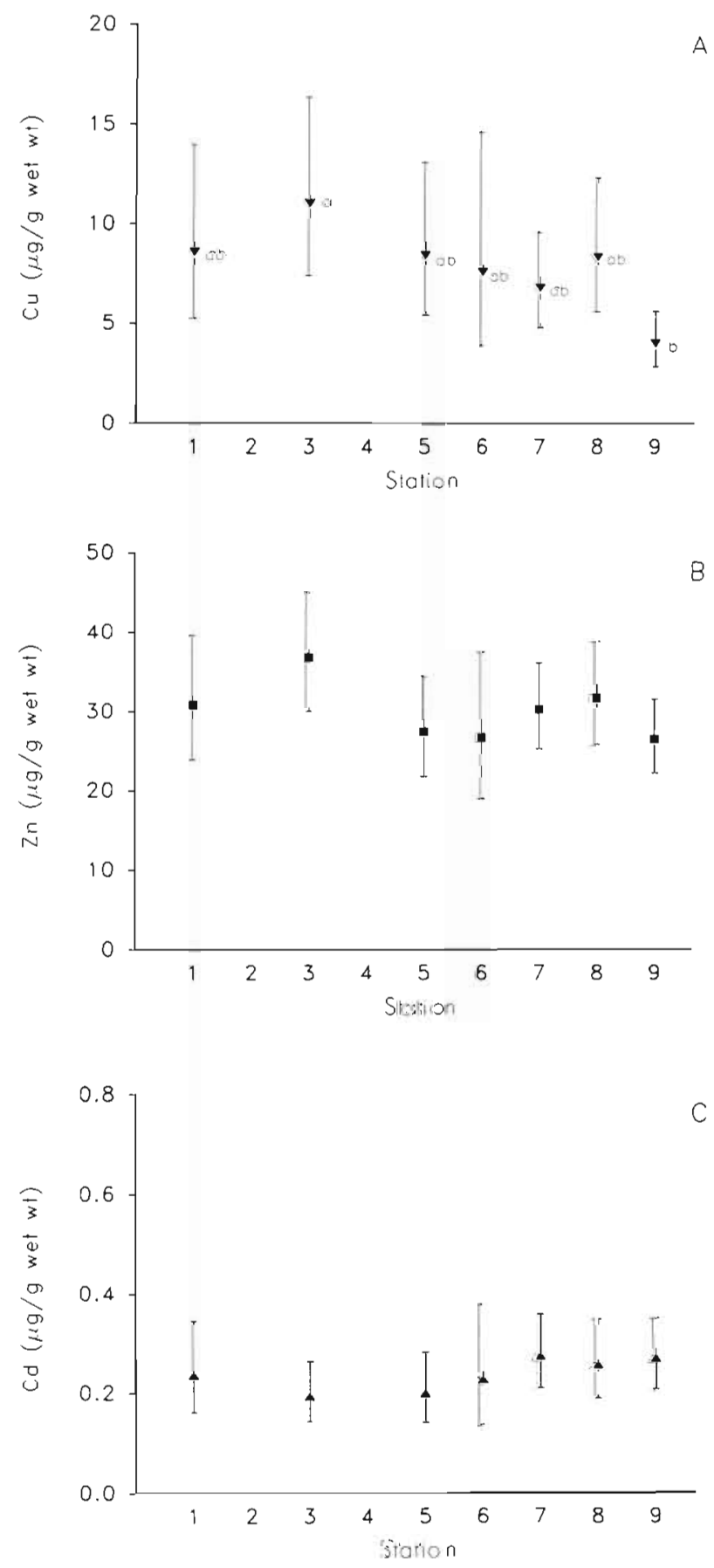

wt, with no significant differences between stations (Fig. 1E). Male liver had a higher $\mathrm{Cd}$ concentration than female liver and the mean value ranged from 0.23 to $0.60 \mu \mathrm{g} \mathrm{g}^{-1}$ (Stns $3 \& 9$, respectively). The hepatic Cd concentration in male dab was significantly lower at Stn 3 compared to Stns 5, 6, 7, 8 \& 9 (Fig. 1F).
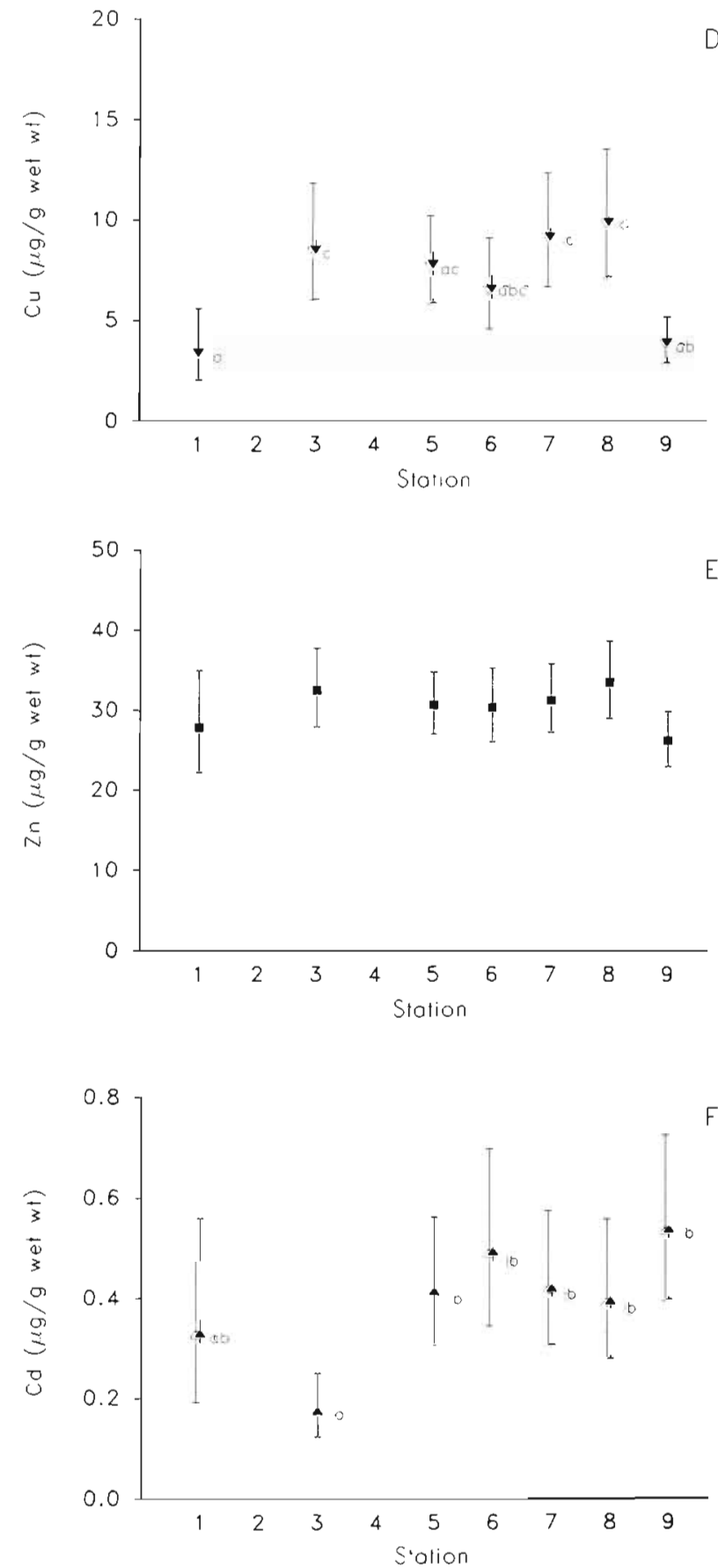

Fig. 1. Limanda limanda. Hepatic metal content in dab from stations in the German Bight. Mean values are given, error bars are $95 \%$ confidence intervals from $\log _{e}$-transformed data. Stations with a common letter subscript were not significantly different in a Tukey HSD-test following a 1-way ANOVA on $\log _{\mathrm{e}}$-transformed data. Female dab: $\mathrm{n}=9,14,11,5,18,14,19$ for Stns 1 to 9 , respectively. (A) $\mathrm{Cu}(\mathrm{p}=0.009$ in ANOVA); (B) $\mathrm{Zn}(\mathrm{p}>0.05)$; $(\mathrm{C}) \mathrm{Cd}(\mathrm{p}>0.05)$. Male dab: $\mathrm{n}=4,9,13,9,11,10,12$ for Stns 1 to 9 , respectively. (D) Cu $(p=0.0001)$; (E) $\mathrm{Zn}(p>0.05)$; (F) Cd $(p=0.0007)$ 


\section{Metallothionein in dab liver}

The mean hepatic metallothionein level was highest in both female and male dab from Stn 7, decreasing towards the coast and towards Dogger Bank (Fig. 2A, B). Female dab collected at Stn 5 had the lowest hepatic MT level, which was significantly lower than in females from Stns 7 \& 8. Similarly, male dab from Stns 1 \& 3 had a significantly lower MT concentration compared to males from Stns $6,7 \& 8$.

Dab of both sexes from Stn 9, at Dogger Bank, had lower hepatic MT levels than dab from Stns $7 \& 8$, but higher than or equal to that of the shoreward stations.

The mean hepatic MT level in males and females was similar at the outermost stations of the transect (Stns 6, 7, 8 \& 9), whereas hepatic MT in female dab was significanily higher than in male at Sins $1 \& 3$, and MT in male dab significantly higher at $\operatorname{Stn} 5$.

\section{Relationships between metals and MT}

In female dab, the hepatic MT content at the 7 stations appeared to reflect both hepatic $\mathrm{Cu}$ and $\mathrm{Zn}$ levels (Figs. 2A \& $1 \mathrm{~A}, \mathrm{~B}$ ). There was little inter-station variability in hepatic $\mathrm{Cd}$ concentrations, and there was no obvious site-dependent relationship between $\mathrm{Cd}$ and MT. In a multiple regression of MT against $\mathrm{Cu}, \mathrm{Zn}$ and $\mathrm{Cd}$ in individual female dab, $\mathrm{Zn}$ alone explained most of the variation accounted for by the 3 metals in the regression $(r=0.52, p<0.0001) . \mathrm{Cu}, \mathrm{Cd}$ or the 2 metals combined did not substantially improve the regression of MT against $\mathrm{Zn}$ when added to the model. This result was supported by non-parametric correlation analysis of MT against $\mathrm{Cu}, \mathrm{Zn}$ and $\mathrm{Cd}$; MT correlated better to $\mathrm{Zn}$ than to $\mathrm{Cu}$ or Cd (Table 1).

In male dab, there were only small differences in the hepatic $\mathrm{Zn}$ level between stations, and accumulation of Zn was not clearly related to the observed interstation differences in MT concentrations (Figs. 1E \& 2B). Hepatic $\mathrm{Cu}$ and $\mathrm{Cd}$ levels appeared to relate better than $\mathrm{Zn}$ to MT content, although no single metal could account for the patterns observed (Figs. 1D-F \& $2 \mathrm{~B}$ ). Contrary to the situation for female dab, multiple regression analysis indicated that $Z n$ did not add substantially to the variation explained by $\mathrm{Cu}$ and $\mathrm{Cd}$ in the regression of MT against those 2 metals ( $r=0.52, p$ values 0.0001 and 0.0004 for $\mathrm{Cu}$ and $\mathrm{Cd}$, respectively). Similarly, significant correlations were found between hepatic MT and both $\mathrm{Cu}$ and $\mathrm{Cd}$ in male dab, but not Zn (Table 1).

There were no obvious relationships between the size of dab (20 to $25 \mathrm{~cm}$ ) and the hepatic concentrations of metals or MT (data not shown).
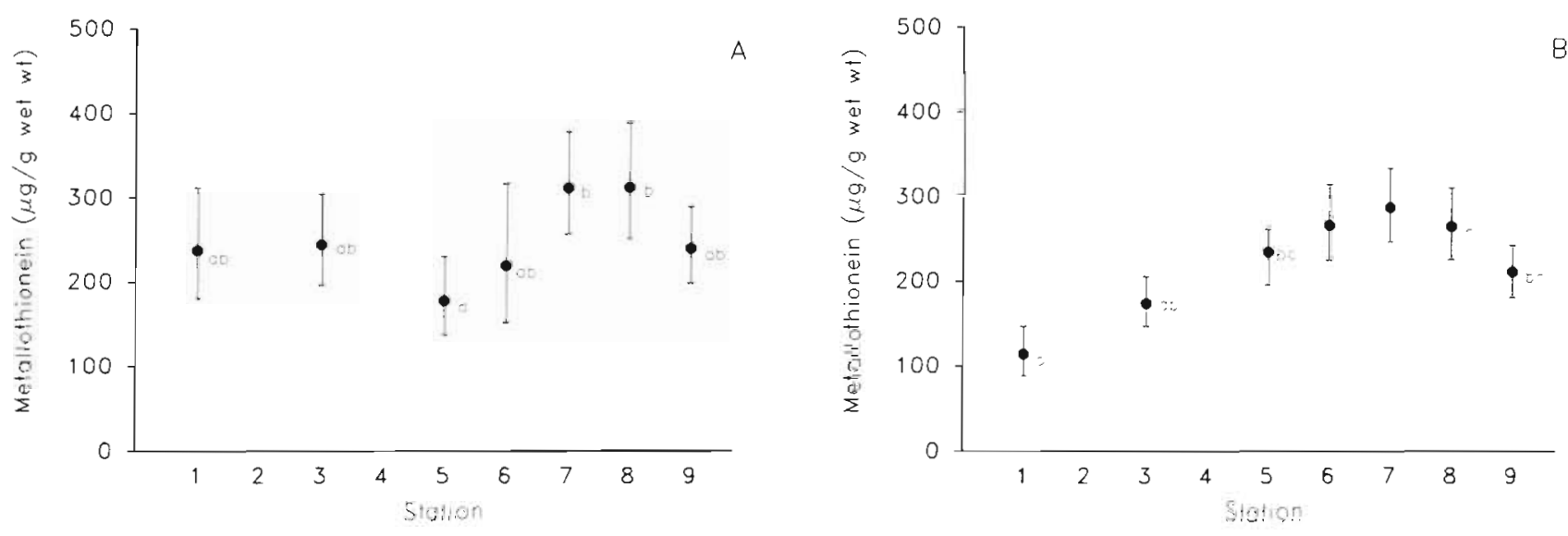

Fig. 2. Limanda limanda. Hepatic metallothionein content of dab from stations in the German Bight. Mean values are given, error bars are $95 \%$ confidence intervals from $\log _{e}$-transformed data. Stations with a common letter subscript were not significantly different in a Tukey HSD-test following a 1 -way ANOVA on $\log _{e}$-transformed data. See caption of Fig. 1 for number of dab analysed from each site. (A) Metallothionein in female dab ( $p=0.015$ in ANOVA); (B) metallothionein in male dab ( $p<0.0001)$ 


\section{DISCUSSION}

The level of hepatic metallothionein reflected the accumulation of the metals $\mathrm{Cu}, \mathrm{Zn}$ and $\mathrm{Cd}$. The highest MT content in both female and male dab was not found in dab collected close to the coast, as could be expected from sediment metal levels, but at stations closer to the Dogger Bank.

In female dab, a major part of the observed changes in hepatic MT reflected an increased hepatic Zn accumulation, possibly triggered by physiological processes related to sexual maturation and spawning. However, MT in female dab also correlated significantly to hepatic $\mathrm{Cu}$ and $\mathrm{Cd}$, which is indicative of an exogenous influence. An indication of the presence of environmental effects was the observed relationship between hepatic MT and $\mathrm{Cd}$ in male dab liver. Metallothionein correlated significantly to $\mathrm{Cu}$ and $\mathrm{Cd}$, whereas no significant relationship was found between hepatic MT and Zn levels. These results are in accordance with previous findings by Olsson et al. (1987), where no significant changes in hepatic $\mathrm{Zn}$ content of sexually maturing male rainbow trout Oncorhynchus mykiss were observed, whereas $\mathrm{Zn}$, and to a lesser extent $\mathrm{Cu}$, increased significantly in maturing females.

The diet of dab at different stations along the gradient presumably reflects the variable composition of the benthic communities (cf. Künitzer 1990, Reise \& Bartsch 1990). Both the benthic invertebrates collected and analyzed during the workshop, i.e. hermit crab Pagurus bernhardus and the polychaete Aphrodite aculeata, contained more metal at offshore than coastal stations (Cofino et al. 1992). The accumulation of metals in invertebrates is highly species-dependent (Eisler 1981), and it was not established in the present study whether these 2 invertebrates were being eaten by the dab. Nevertheless, it appears likely that a substantial part of the increased hepatic metal accumulation in dab at the offshore stations was caused by dietary metal uptake. Interestingly, Stagg et al. (1992) found agreement between sediment metal levels and the concentrations of metals and MT in the gills of the same female dab.

An additional problem posed by Rijnsdorp et al. (1992) concerns the uncertain origin of dab collected at any station due to the spawning migration. They suggest that there is a general movement of sexually maturing dab towards an area in the vicinity of Stn 5 in the initial part of the spawning period, and that males are somewhat more stationary than females. In the present context, this would imply that dab caught at Stns 3 \& 5 represented a mixed group of coastal and offshore dab, whereas dab collected at the offshore stations represented mainly offshore dab. In addition, male dab could be expected to reflect the local exposure conditions more than females

Hepatic MT has been found to increase markedly within $2 \mathrm{wk}$ in other flatfish species exposed to $\mathrm{Cd}$ or Zn (George \& Young 1986, Overnell et al. 1987a), and the half-life of Zn-induced hepatic MT in flatfish has been estimated to $4 \mathrm{wk}$ (Overnell et al. 1987a). McCarter \& Roch (1984) reached the same estimate for Cu-bound MT in salmonids. Dab caught in a comparatively clean area within 1 mo of migration from a more contaminated area would therefore still have elevated hepatic MT and metal concentrations. Furthermore, levels of the protein would remain elevated only in fish under a sustained metal burden.

Male dab collected at Stn 1, i.e. the station with the most highly metal-contaminated sediment (Cofino et al. 1992), had the lowest mean hepatic MT level of either male or female at any site. A similar situation was observed in a study of white croakers Genyonemus lineatus at control and contaminated stations off the Californian coast (Brown et al. 1982). They suggested that high sediment levels of pesticides and organic contaminants inhibited the uptake and accumulation of metals in the fish. The effects of such pollutants on metal uptake or on fish metallothionein levels are not clear. George \& Young (1986) found no effect of intraperitoneal injection of 3 -methylcholanthrene on hepatic MT in plaice Pleuronectes platessa. Likewise, Ariyoshi et al. (1990) observed no change in carp Carassius auratus hepatic MT following pesticide intraperitoneal injections. Finally, in flounder Platichthys flesus captured along a pollution gradient during the GEEP workshop in 1986, there was a clear seaward trend of decreasing effects on several organochlorineand pesticide-sensitive biomarkers (cf. Addison 1988), but MT did not follow the pattern of these biomarkers (Overnell \& Abdullah 1988). Thus, it appears likely that the observed differences in hepatic MT levels were not affected by the impact of organic compounds on dab. Instead, they were caused by differences in hepatic metal accumulation.

The mean hepatic Cu level of male dab at Stns 5 to 8 was of a similar magnitude to that of $\operatorname{Stn} 3 \mathrm{dab}$. The low Cu content in both female and male dab from Stn 9 corresponded to low total sediment $\mathrm{Cu}$ at that station (Cofino et al. 1992), but the higher hepatic values at Stns 5 to 8 did not fit in with the decrease in total sediment $\mathrm{Cu}$ at the offshore stations. The hepatic $\mathrm{Cu}$ level in most of the dab from the German Bight was lower than observed in unexposed dab by Overnell \& McIntosh (1988), but somewhat higher than the values found by Cofino et al. (1992) for dab collected during this workshop. The mean hepatic $\mathrm{Cu}$ level of female dab from Stn 3 was similar to that of dab fed excess dietary $\mathrm{Cu}$ (19.3 $\mathrm{Mg} \mathrm{g}^{-1}$ wet wt; Overnell \& McIntosh 1988). 
The hepatic $\mathrm{Zn}$ level was of similar magnitude at all stations for both sexes, and there seems to be no influence of the increased total sediment $\mathrm{Zn}$ content at the innermost stations (cf. Cofino et al. 1992). Overnell \& McIntosh (1988) found a lower hepatic Zn content in dab than that observed in the present study $(20$ compared to $30-40 \mu \mathrm{g} \mathrm{g}^{-1}$ wet $\mathrm{wt}$ ), but the authors provide no information on season or the sex of their experimental fish. This is of importance, because hepatic $\mathrm{Zn}$ is known to increase considerably during sexual maturation in female salmonids (Olsson et al. 1987, 1989). Presumably, this also applies to dab and other flatfish species (Overnell et al. 1987b).

The elevated hepatic Cd content observed in male dab collected at Stns 5 to 9 compared to dab collected closer to the coast is in agreement with the results of other studies (Harms 1990, Cofino et al. 1992). The source of $\mathrm{Cd}$ and the reasons for these findings are not known. An interesting result from the present study was that hepatic $\mathrm{Cd}$ in male dab was twice as high as in females collected at Stns 5 to 9 . The dab studied were adult individuals in maturation or spawning (cf. Daan et al. 1990), and the observed sexual difference may have been caused by incorporation of $\mathrm{Cd}$ into gonads in female dab (cf Baer \& Thomas 1991, Povlsen et al. 1990), thereby increasing the otherwise slow excretion of the metal. Of greater consequence is probably the age-difference between male and female dab in the size group examined ( 20 to $25 \mathrm{~cm}$ ). Male dab were 6 to 7 yr and older, whereas female dab in the same size range were 4 to 5 yr and older (Rijnsdorp et al.1992). Older fish (i.e. males) could be expected to accumulate more $\mathrm{Cd}$, as the metal has a long biological half-life.

For both females and males, the highest mean MT level was only about double that of the lowest mean. Even though mean hepatic MT levels in German Bight dab were somewhat elevated compared to Scottish and Swedish dab from relatively unpolluted areas (Overnell \& McIntosh 1988, Hogstrand unpubl.), the German Bight dab do not appear to be grossly influenced by heavy metal pollution. In association with MT levels, hepatic concentrations of $\mathrm{Cu}, \mathrm{Zn}$ and $\mathrm{Cd}$ indicated that both female and male dab in the German Bight are moderately affected by environmental $\mathrm{Cu}$ and $\mathrm{Cd}$, and that this influence appears to be most marked for offshore dab. The discrepancy between sediment metal levels and the concentrations of metals and MT in dab livers may be ascribed to spawning migration, differently contaminated diet or a combination of the two. Furthermore, the elevated $\mathrm{Cd}$ and MT levels found in $\mathrm{dab}$ at the outermost stations of the transect imply that there are other metal inputs into the German Bight in addition to the Weser and Elbe estuaries, even though such inputs were not reflected in the sediment analyses of the present workshop (Cofino et al. 1992).

\section{Evaluation of methods and recommendations}

In the above discussion, we have argued that hepatic MT concentration reflected hepatic heavy metal levels in both male and female dab. Some differences were observed between the sexes, presumably mainly related to sexual maturation. However, hepatic MT concentrations and the levels of $\mathrm{Cu}, \mathrm{Zn}$ and $\mathrm{Cd}$ permitted a distinction to be made between the environmental and endogenous component for each sex. Furthermore, there appeared to be little effect of contaminants other than metals on hepatic MT, as found by comparing $\mathrm{MT}$ levels at different stations with the hepatic accumulation of other contaminants (cf. Cofino et al. 1992) or the level of biomarkers sensitive to organic pollutants (cf. Galgani et al. 1992, Goksøyr et al. 1992, Moore 1992).

The authors would like to make the following recommendations for future use of fish hepatic metallothionein in monitoring:

(1) Selection of fish: the fish used should preferably be juvenile. The sexes must be analyzed separately if maturing or mature fish are used. This is essential if the species is collected the month before or during spawning. In addition, the fish species used should be known to spend most of the year in the vicinity of the selected stations.

(2) Need for accompanying analyses: quantification of metallothionein should be complemented with analyses of hepatic $\mathrm{Cu}, \mathrm{Zn}$ and $\mathrm{Cd}$ to enable assessment of the effects of individual metals. In most studies, a minimum of identification of the component being measured would be required (i.e. MT).

(3) Problems related to the quantification of metallothionein: methods should be used that include metallothionein associated with strongly bound metals, i.e. $\mathrm{Cu}$ and $\mathrm{Hg}$. For most applications, immunoassays would be the method of choice, but differential pulse polarography (DPP) would also be acceptable (cf. Hogstrand \& Haux 1992)

Acknowledgements. We thank IOC, ICES and the Alfred Wegener Institule for organizing and housing the workshop, and also the crew of RV 'Victor Hensen' This study was funded by the Research Committee of the National Swedish Environmental Protection Board and by a grant to K.H. from the Norwegian Fisheries Research Council.

\section{LITERATURE CITED}

Addison, R. F. (1988). Biochemical effects of a pollutant gradient - summary. Mar. Ecol. Prog. Ser. 46: 75-77

Ariyoshi, T. Shiiba, S., Hasegawa, H. Arizono, K. (1990). Profile of metal-binding proteins and heme oxygenase in red carp treated with heavy metals, pesticides and surfactants. Bull. environ. Contam. Toxicol. 44: 643-649

Baer, K. N., Thomas, P. (1990). Influence of capture stress, 
salinity and reproductive status on zinc associated with metallothionein-like proteins in the livers of three marine teleost species. Mar. environ. Res. 29: 277-287

Baer, K. N., Thomas, P. (1991). Isolation of novel metalbinding proteins distinct from metallothionein from spotted seatrout (Cyonoscion nebulosus) and Atlantic croaker (Micropogonias undulatus) ovaries. Mar. Biol. 108: $31-37$

Brown, D. A., Jenkins, K. D., Perkins, E. M., Gossett, R. W. Hershelman, G. P. (1982). Detoxification of metals and organic compounds in white croakers. In: Bascom, W. (ed.) Coastal water research project, biennial report 1981-82. Long Beach, California, p. 157-172

Cofino, W. P., Smedes, F, de Jong, S. A., Abarnou, A., Boon, J. P., Oostingh, I., Davies, I., M., Klungsøyr, J., Law, R. J., Whinnett, J. A., Schmidt, D., Wilson, S. (1992). The chemistry programme. Mar. Ecol. Prog. Ser. 91: 47-56

Daan, N., Bromley, P. J., Hislop, J. R. G., Nielsen, N. A. (1990). Ecology of North Sea fish. Neth. J. Sea Res. 26: 343-386

Day, R. W., Quinn, G. P. (1989). Comparisons of treatments after an analysis of variance in ecology. Ecol. Monogr. 59: $433-463$

Eisler, R. (1981). Trace metal concentrations in marine organisms. Pergamon Press, New York

Engel, D. W., Brouwer, M. (1989). Metallothionein and metallothionein-like proteins: physiological importance. Adv. comp. environ. Physiol 5: 53-75

Engel, D. W., Roesijadi, G. (1987). Metallothioneins: a monitoring tool. In: Vernberg, W. B., Calabrese, A., Thurberg, F. P., Vernberg, J. F. (eds.) Pollution physiology of estuarine organisms. University of S. Carolina Press, Columbia p. $421-438$

Galgani, F., Bocquené, G., Cadiou, Y. (1992). Evidence of variation in cholinesterase activity in fish along a pollution gradient in the North Sea. Mar. Ecol. Prog. Ser. 91: 77-82

George, S. G. (1990). Biochemical and cytological assessment of metal toxicity in marine animals. In: Furness, R. W. Rainbow, P. S. (eds.) Heavy metals in the environment. CRC Press, Boca Raton, p. 124-142

George, S. G., Young, P. (1986). The time course of effects of cadmium and 3-methylcholanthrene on activities of enzymes of xenobiotic metabolism and metallothionein levels in the plaice, Pleuronectes platessa. Comp. Biochem. Physiol 83C: $37-44$

Goksøyr, A., Larsen, H. E., Blom, S., Förlin, L. (1992) Detection of cytochrome P450 1A1 in North Sea dab liver and kidney. Mar. Ecol. Prog. Ser. 91: 83-88

Harms, U. (1990). Schwermetalle Cadmium, Blei und Quecksilber in Fischen. In: Lozan, J. L., Lenz, W., Rachor, E., Watermann, B., von Westernhagen, H. (eds.) Warnsignale aus der Nordsee. Verlag Paul Parey, Berlin, p. $267-274$

Haux, C., Förlin, L. (1988). Biochemical methods for detecting effects of contaminants on fish. Ambio 17: 376-380

Haux, C., Förlin, L. (1989). Selected assays for health status in natural fish populations. In: Landner, L. (ed.) Chemicals in the aquatic environment. Springer-Verlag, Berlin, p. $197-215$

Hogstrand, C., Haux, C. (1990a). Metallothionein as an indicator of heavy-metal exposure in two subtropical fish species. J. exp. mar. Biol. Ecol. 138: 69-84

Hogstrand, C., Haux, C. (1990b). A radioimmunoassay for perch (Perca fluviatilis) metallothionein. Toxicol appl. Pharmacol. 103: 56-65

Hogstrand, C., Haux, C. (1991). Binding and detoxification of heavy metals in lower vertebrates with reference to metallothionein. Comp. Biochem. Physiol. 100C: 137-142
Hogstrand, C., Haux, C. (1992). Evaluation of differential pulse polarography for the quantification of metallothionein - a comparison with RIA. Analyt. Biochem. 200: 388-392

Hogstrand, C., Lithner, G., Haux, C. (1991). The importance of metallothionein for the accumulation of copper, zinc and cadmium in environmentally exposed perch, Perca fluviatilis. Pharmacol. Toxicol. 68: 492-498

Hyllner, S. J., Andersson. T., Haux, C., Olsson, P.-E. (1989). Cortisol induction of metallothionein in primary culture of rainbow trout hepatocytes. J. cell. Physiol. 139: 24-28

Künitzer, A. (1990). A comparison of the Amphiura filiformis associations north-east of the Dogger Bank and of the German Bight. Neth. J. Sea Res. 25: 199-208

McCarter, J. A., Roch, M. (1984). Chronic exposure of coho salmon to sublethal concentrations of copper - III. Kinetics of metabolism of metallothionein. Comp. Biochem. Physiol. $77 \mathrm{C}$ : $83-87$

Moore, M. (1992). Molecular cell pathology of pollutantinduced liver injury in flatfish: use of fluorescent probes. Mar. Ecol. Prog. Ser. 91: 127-133

Olafson, R., Sim, R. (1979). An electrochemical approach to quantitation and characterization of metallothionein. Analyt. Biochem. 100: 343-351

Olsson, P.-E., Haux, C. (1986). Increased hepatic metallothionein content correlates to cadmium accumulation in environmentally exposed perch (Perca fluviatilis). Aquat. Toxicol. 9: 231-242

Olsson, P.-E., Haux, C., Förlin, L. (1987). Variations in hepatic metallothionein, zinc and copper levels during an annual reproductive cycle in rainbow trout, Salmo gairdneri. Fish Physiol. Biochem. 3: 39-47

Olsson, P.-E., Zafarullah, M., Gedamu, L. (1989). A role of metallothionein in zinc regulation after oestradiol induction of vitellogenesis in rainbow trout, Salmo gairdneri. Biochem. J. 257: 555-559

Overnell, J., Abdullah, M. I. (1988). Metallothionein and metal levels in flounder Platichthys flesus at four field stations and in flounder dosed with water-borne copper. Mar. Ecol. Prog. Ser. 46: 71-74

Overnell, J., McIntosh, R. (1988). The effect of supplementary dietary copper on copper and metallothionein levels in the fish, dab, Limanda limanda. Mar. environ. Res. 26: $237-247$

Overnell, J., McIntosh, R., Fletcher, T. C. (1987a). The enhanced induction of metallothionein by zinc, its half-life in the marine fish Pleuronectes platessa, and the influence of stress factors on metallothionein levels. Experientia 43: 178-181.

Overnell, J., McIntosh, R, Fletcher, T. C. (1987b). The levels of liver metallothionein and zinc in plaice, Pleuronectes platessa L., during the breeding season, and the effect of oestradiol injection. J. Fish Biol. 30: 539-546

Povlsen, A. F., Korsgaard, B., Bjerregaard, P. (1990). The effect of cadmium on vitellogenin metabolism in estradiol-induced flounder (Platichthys flesus (L.)) males and females. Aquat. Toxicol. 17: $253-262$

Reise, K., Bartsch, I. (1990). Inshore and offshore diversity of epibenthos dredged in the North Sea. Neth. J. Sea Res. 25: $175-179$

Rijnsdorp, A. D., Vethaak, A. D., van Leeuwen, P. I. (1992). Population biology of dab Limanda limanda in the southeastern North Sea. Mar. Ecol. Prog. Ser. 91: 19-35

Roch, M., McCarter, J. A. (1984). Hepatic metallothionein production and resistance to heavy metals by rainbow trout (Salmo gairdneri) - II. Held in a series of contaminated lakes. Comp. Biochem. Physiol. 77C: $77-82$ 
Sabourin, T. D., Gant, D. B., Weber, L. J. (1986). The influence of metal and nonmetal stressors on hepatic metal-binding protein production in buffalo sculpin, Enophrys bison. In: Vernberg, F. J., Thurberg. F. P., Calabrese, A., Vernberg, W. B. (eds.) Marine pollution and physiology: recent advances. University of S. Carolina Press, Columbia, p. $247-266$

Siegel, S. (1956). Non-parametric statistics for the behavioral sciences. McGraw-Hill, New York

Snedecor, G. W., Cochran, W. G. (1980). Statistical methods, 7 th edn. Iowa State University Press, Ames
Sokal, R. R., Rohlf, F. J. (1981). Biometry. W. H. Freeman, New York

Stagg, R., Goksøyr, A., Rodger, G. (1992). Changes in branchial $\mathrm{Na}^{+}, \mathrm{K}^{+}$-ATPase, metallothionein and P450 1A1 in dab Limanda Jimanda in the German Bight: indicators of sediment contamination? Mar. Ecol. Prog. Ser. 91: $105-115$

Sulaiman, N., George, S., Burke, M. D. (1991). Assessment of sublethal pollutant impact on flounders in an industrialised estuary using hepatic biochemical indices. Mar. Ecol. Prog. Ser. 68: 207-212 